\title{
A Comparative Analysis of the Public and Private Water Supply and Sanitation Service Providers' Work in Brazil
}

\author{
Fernando Antonio Perrone Pinheiro ${ }^{\dagger}$ \\ São Paulo University \\ José Roberto Ferreira Savoia ${ }^{\Omega}$ \\ São Paulo University \\ Claudio Felisoni de Angelo ${ }^{¥}$ \\ São Paulo University
}

\begin{abstract}
This paper aims to evaluate the performance of the private management of water supply and sanitation services in Brazil. We can verify therefore, whether this management model has presented superior performance compared to the model of public management. The analysis was based on various economic-financial and operational indices related to water supply and sewage collection and treatment between 2000 and 2010. The results indicate that private companies outperform public entities in several aspects, like productivity, investment, return and access to these services, pointing out the concessions and public-private partnerships are feasible ways to reach political targets of universalization of Water Supply and basic Sanitation.
\end{abstract}

Keywords: Water supply and basic sanitation. Concession. Public-private partnership. Infrastructure.

$\Omega$ Doctor by Faculdade de Economia, Administração e Contabilidade da Universidade de São Paulo com PósDoutorado Columbia University Institution: Professor da Universidade de São Paulo

Address: Av. Prof. Luciano Gualberto, 908 - Butantã, São Paulo - SP - Brazil CEP 05508-010

E-mail: jrsavoia@usp.br

Telephone: + 55 (11) 3818-4030

\footnotetext{
${ }^{¥}$ Doctor by Faculdade de Economia, Administração e Contabilidade da Universidade de São Paulo. Institution: Professor Titular da Universidade de São Paulo Address: Av. Prof. Luciano Gualberto, 908 - Butantã, São Paulo - SP - Brazil CEP 05508-010 E-mail: cfa@usp.br Telephone: +55 (11) 3894-5006
}

Note from the Editor: The article was accepted by Emerson Mainardes. 


\section{INTRODUCTION}

he extension and the quality of the infrastructure are determining factors for the development of a country. Ascher and Krupp (2006) state that infrastructure is the backbone of a developed economy and a pillar of quality of life.

The lack of infrastructure investments has been identified in Brazil. According to Pinheiro (in OLIVEIRA et al, 2013, p. 103), it has been 3 decades since the country invests a little over $2 \%$ of its GDP, whilst its direct competitors in the international market and Latin American countries invest from 4\% to $8 \%$ of

their GDP. Deficiencies in infrastructure greatly affect the population, representing an obstacle to social welfare.

To provide water supply and sanitation infrastructure is a public health issue. The PNUD (2006) (United Nations Development Program) in their Human Development Report, it is observable that worldwide, one million eight hundred thousand children die each year from diarrhea and other diseases, as a result of unsuitable water for human consumption and the and the absence of sewer installations. This is the second leading cause of infant mortality in the early 21 st century. Furthermore, investment in water supply and sanitation provides productivity gains and savings of public resources in health, as for for every US\$1 invested it is possible to generate a potential benefit estimated between US\$5 and US $\$ 28$, depending on the country (HUTTON; HALLER, 2004).

In order to meet the investment needs, governments have adopted models that lead to a greater private sector participation in the provision of public services, through privatizations, concessions and public-private partnerships. These models have been disseminated by most countries, becoming a widespread and relevant practice within the public sector reform process, being intensified from the eighties.

In this paper four complementary analysis are developed with the objective to verify whether private management of the water supply and sanitation services have presented a higher performance compared to public management, in operational, administrative and financial terms. In addition, we evaluated the willingness to invest and to achieve the goal of services universalization. For this end, we used a database of 1.203 providers of these services in Brazil between 2000 and 2010, this data coming from the SNIS (National Sanitation Information System). 
The main contribution of the paper is to verify whether the decisions to delegate management of water supply and sewage services to the private sector provided the expected results, with the objective of universalizing services. Another contribution is to trigger discussion on performance metrics which can be used in periodic reviews of tariffs and contract renegotiations.

The paper is organized over five sections, including this introduction. In the second section we go through the literature review on the theme. The third section presents the methodology and in the fourth section we present the results of the research. In the fifth section are the conclusions of this study.

\section{LITERATURE REVIEW}

\subsection{CONCESSIONS AND PUBLIC-PRIVATE PARTNERSHIPS}

According to Evans et al (2004), the introduction of the private sector in providing urban water services provides a unique opportunity to address a service economic policy for the poor and informal communities. For Guasch et al (2007), from the eighties on, the trend in Latin America and the Caribbean to transfer the provision of public services to the private sector began, due to the need to invest in infrastructure, the scarcity of public resources and from the assumption of greater efficiency of the private sector. These transfers took several forms, such as management contract, concession or privatization.

According to Silvestre (2012) the reasoning for the change in the provision of public sector services to the private sector has its genesis in the belief that there would be more efficiency and productivity and focus on users' needs, when that latter were responsible for the services. According to Bennett (20120, since private companies work in pursuit of profits they would always tend to increase their productivity, achieving higher performance.

It should be admitted that part of the lower efficiency of the public sector stems from the restrictions issued by regulatory standards imposed on the public administrator, or due to the absence of an incentive structure that induces the civil service to achieve higher goals consistently. In addition, Mello (apud SHINOHARA; SAVOIA, 2008, p. 4) also cites the agency cost of the public sector, whose governance becomes more complex due to the existence of a third agent, politicians who prioritize maximizing their budgets instead of efficiency, because of the political prestige that it entails.

However, as pointed by Ruester and Zschille (2010), there is no consensus on the best way to achieve this goal among the various modes: public-private partnerships, concessions 
and privatizations. This is due to differences among countries in their legislation, practices and institutions that lead to different results among countries.

In sum, private service providers present as advantages: (i) their greater access to the necessary capital in order to invest, given the fiscal situation of states and municipalities making them unable to obtain credit; (ii) insertion into a more flexible legal and regulatory environment, without the binding nature of the Bidding Law, conferring the private sector greater flexibility in the business management; (iii) labor relations without the inefficiencies of the public sector, allowing greater ability to achieve efficiency; (iv) the non-existence of agency cost of the public sector; (v) access to human and material resources in order to seek new technologies that will result in the improvement of the services provided; (vi) their motivation for efficiency gains; and (vii) the competitiveness of the bidding process, which contributes to the practice of reasonable tariffs.

It must be considered that the provision of public services represents the concession to operate a monopoly, and its surrender to the private sector must ensure that the agent keeps the quality of services and the practice of reasonable tariffs. Da Motta and Moreira (2006), who researched the monopoly power of service providers between 1998 and 2002, obtained evidence that, in the absence of incentives for improved efficiency, service providers relieve productivity and apply higher tariffs.

The need for regulation in the sector and proper accountability is emphasized by several authors, such as Locussol (2006), Kessides (2004) and Brocklehurst and Janssens (2004). Seen in these terms, it is appropriate to quote the World Bank's recommendation, in which the pertinent regulation regarding water supply must achieve three goals, of economic and social well-being character: (i) efficiency in production and in supplying water, at the lowest possible cost; (ii) equal access to the entire population at affordable prices and with a quality service delivery; and (iii) sustainability from an environmental viewpoint, to minimize damage to natural resources (KESSIDES, 2004).

It should be noted that the delegation of basic sanitation services to private agents is not risk-free. For example, Uruguay, who had started the sector's privatization in 1993, went back on its decision a decade later due to perceived deterioration of water quality and the high tariffs imposed on the population. These facts led to the enactment in 2004 of a law establishing for such services to be an exclusive assignment of public administration (BORRAZ et al, 2013). 
It is necessary, therefore to check whether the concessions and public-private partnerships (PPPs) have brought tangible benefits to society, and whether this activity has been conducted by private companies more efficiently. Thus, the justification of this work resides in the investigation of the existence of benefits when conceding public water supply and sanitation services to the private sector, considering the possibility of their better performance, including, the achievement of public policies objectives and of universalization.

\subsection{THE EFFICIENCY OF PUBLIC AND PRIVATE WATER SUPPLY AND SANITATION SERVICE PROVIDERS}

In international literature, the results of comparisons between the performance of public and private providers are not conclusive. Walter et al (2009) produced an extensive literature review to investigate the influence of organizational structure on business performance. Bhattacharyya et al (1995 apud WALTER et al, 2009) studied 221 water supply companies in the US in 1992 and concluded that the public companies have lower costs, and tend to be more efficient than private providers. Etache and Kouassi (2002 apud WALTER et al, 2009) and Kirkpatrick et al (2006 WALTER et al, 2009) studied the performance of African water supply companies by means of the Cobb-Douglas production function, using similar data for both studies: as input variables the cost of labor, materials, energy, among others, and as an output variable the volume of water produced; the first study pointed to the greater efficiency of private companies, while the second showed that eventual differences are not significant. García-Sánchez (2006 WALTER et al, 2009) conducted a data envelopment analysis of the performance of 24 service providers in Spain considering as predictors variables the staff, the treatment plants, the cost per kilometer; and as dependent variables the amount of water produced and the number of connections; as a result, we found no significant differences between the performance of private and public providers.

Renzetti and Dupont (2003), in their study on the relationship between the origin of the capital and the performance of water supply and sanitation service providers in the US, United Kingdom and France, did not obtain strong evidence that private providers outperform the public providers.

Saal et al (2007), studied 10 providers of water supply and sanitation service in the UK between 1985 and 2000, and concluded that efficiency does not stem only from the origin of capital, but also from the regulatory regime. After the sector's privatization, efficiency decreased, due to the changes arising from the privatization itself combined with the less 
restrictive price limits policy (price cap). With the changes in this policy from 1994 onwards, these limits altered and most efficiency losses were recovered.

Brocklehurst and Janssens (2004), when studying the contracts with the private sector in countries from Central and Western Africa, related the period length from the beginning of the PPP contracts to the amount of dedicated staff, per 1000 water connections, and found significant reduction in the workforce, in spite of the distortions caused by illegal connections and the difficulty of measuring the service.

In Brazil, Tupper and Resende (2004) conducted a study on efficiency and regulation, analyzing 20 state companies between 1996 and 2000, by means of data envelopment analysis (DEA). It was found that performance is a function of the system water losses and the density of water supplying services, given by the relation of the population served and the extension of the supply network. The conclusion is that parameters of this nature should be considered in the implementation of mechanisms to encourage competition.

Sabbioni (2008), by examining the efficiency of water supply and sanitation service providers in Brazil between 2000 and 2004, concluded that regional state companies, have the lowest specific costs, which stems from the economy of scale. In addition, local private operators have specific costs similar to those of local public enterprises, while other local public providers have the highest specific costs.

Ferro et al (2004) studied the cost structure of the water supply and sanitation service providers between 2003 and 2010 and comment that the administrative independence is not relevant to explain the cost structure but the origin of capital does, since private companies have a lower cost structure. Also according to the authors, independent operators have better cost management and professional training; by contrast, the dependents have subsidies, such as office space, information technology, administration, and others.

\section{METHODOLOGY}

The research objectives and the methodology used are summarized in Table 1. 


\begin{tabular}{|c|l|l|l|l|}
\hline Topic & $\begin{array}{l}\text { Researched } \\
\text { aspect }\end{array}$ & Research problem & Indexes used & Methodology used \\
\hline 1 & $\begin{array}{l}\text { Performance } \\
\text { analysis }\end{array}$ & $\begin{array}{l}\text { To investigate what } \\
\text { providers present better } \\
\text { performance, under the } \\
\text { economic-financial and } \\
\text { operational perspective, } \\
\text { according to its legal } \\
\text { nature. }\end{array}$ & $\begin{array}{l}\text { Rates of consumption, } \\
\text { loss of productivity, } \\
\text { financial performance, } \\
\text { access to services, etc. }\end{array}$ & $\begin{array}{l}\text { Descriptive statistics and } \\
\text { the comparison between } \\
\text { the average rates of } \\
\text { 2010 service providers. }\end{array}$ \\
\hline 2 & $\begin{array}{l}\text { Willingness } \\
\text { to invest }\end{array}$ & $\begin{array}{l}\text { To investigate which } \\
\text { service providers invest } \\
\text { the most. }\end{array}$ & $\begin{array}{l}\text { Amounts invested in } \\
\text { concessions in the five } \\
\text { years between 2006 and } \\
\text { 2010. }\end{array}$ & $\begin{array}{l}\text { Descriptive statistics and } \\
\text { comparison between the } \\
\text { investments made during } \\
\text { the period. }\end{array}$ \\
\hline 3 & $\begin{array}{l}\text { Service } \\
\text { universalizat } \\
\text { ion }\end{array}$ & $\begin{array}{l}\text { To investigate which } \\
\text { providers have achieved } \\
\text { greater success in the } \\
\text { universalization of } \\
\text { services. }\end{array}$ & $\begin{array}{l}\text { Evolution of the indexes } \\
\text { of access to services } \\
\text { between 2005 and 2010. }\end{array}$ & $\begin{array}{l}\text { Descriptive statistics and } \\
\text { comparison of the change } \\
\text { in rates between 2005 and } \\
\text { 2010. }\end{array}$ \\
\hline 4 & $\begin{array}{l}\text { Ability to } \\
\text { communicat } \\
\text { eroductivity } \\
\text { gains }\end{array}$ & $\begin{array}{l}\text { To investigate which } \\
\text { providers are better able to } \\
\text { communicate productivity } \\
\text { gains to rate. }\end{array}$ & $\begin{array}{l}\text { Sanitation public tariffs } \\
\text { and indexes of } \\
\text { productivity. }\end{array}$ & $\begin{array}{l}\text { Panel Static analysis for } \\
\text { the city and for the year of } \\
\text { information (2000, 2005 } \\
\text { and 2010). }\end{array}$ \\
\hline
\end{tabular}

Table 1 - Summary of Research Objectives

Source: Developed by the authors.

On topics 1, 2 and 3, the verification of the significance of the differences between the means of the variables grouped by type of service provider, we used the ANOVA test, whose use is subject to the normality of the variables (HAIR JUNIOR et al, 2009; p. 322); otherwise we shall use the Kruskal Wallis' test. The normality test we used the Kolmogorov-Smirnov.

The regression on topic 4 aims to verify the correlation between tariff and productivity indexes, according to the legal nature of the service provider. The dependent variable is the tariff, and the explanatory variables are the selected productivity indexes, individually. We did not consider more than one index per regression given the existing colinearity between the same. Dummy variables were created to identify public sector and mixed capital companies.

The model used is the static panel, indexed by year and by municipality. We used Hausman's test to choose between panels with fixed effects or random effects. Several municipalities do not have information for all years studied, setting an unbalanced panel (STOCK; WATSON, 2004, p.186). The major regression coefficients indicate that the tariff practiced by that provider finds a better explanation in its cost structure, which opens the possibility to share productivity gains with the population served. The existence of significance for the coefficients will be checked by Wald's test. The regression used is shown below: 


$$
\text { Tariff }=\alpha_{1}+\beta_{1} \text { Vartest }+\alpha_{2} D_{2}+\beta_{2} D_{2} \text { Vartest }+\alpha_{3} D_{3}+\beta_{3} D_{3} \text { Vartest }
$$

In which:

Tariffs refers to the tariff of water and sewage practiced in the city.

Vartest is the tested productivity index.

$\mathrm{D}_{2}$ is a dummy for the public sector, including the direct, local authorities and public companies. $\mathrm{D}_{3}$ is the dummy for mixed capital companies with public and private administration.

I | is the intercept

$\beta_{1}$ is the slope (declivity) coefficient of Vartest.

$\alpha_{2}$ and $\alpha_{3}$ are the coefficients for $D_{2}$ e $D_{3}$, i.e., the additional intercept for these dummies.

$\beta_{2}$ and $\beta_{3}$ are the coefficients of the interactions between Vartest and dummies $D_{2}$ and $\mathrm{D}_{3}$ and represent the additional declivity on private providers. Along with $\beta 1$, they will provide answer to the research question.

The interaction between a dummy variable and a continuous independent variable is used in order to check the declivity associated with the dummy (WOOLDRIDGE, 2012, p. 226; STOCK; WATSON, 2004, p.150). Thus, as we intend to measure the correlation between a given index of productivity and the practiced tariff for each sector (public, private, mixed capital), the coefficients of the interaction variables shall provide the desired result.

The analysis conducted only includes data on water supply and sanitary sewage systems. What does not fall under the scope of this study are the treatment of solid waste, cleaning and systems and rainwater harvesting, although they are included in the definition of sanitation in the Law 11.445/2007, which is the regulatory framework for the sector.

All information has been extracted from SNIS (National Sanitation Information System), relating the entrusted supplier of the service (Table 2). In some situations, the SNIS omits the identification of the private concessionaire and relates only the public entity conceding the services. 
Table 2 - Number of Records in the SNIS - Water Supply and Sewage Services

\begin{tabular}{l|rrr|}
\hline Legal nature of the service provider legal & \multicolumn{3}{c|}{ Year } \\
\cline { 2 - 4 } & $\mathbf{2 0 0 0}$ & $\mathbf{2 0 0 5}$ & $\mathbf{2 0 1 0}$ \\
\hline Direct public administration & 25 & 107 & 700 \\
Regional authority & 145 & 251 & 406 \\
Private company & 13 & 25 & 54 \\
Public company & 1 & 6 & 5 \\
Social organization & - & - & 3 \\
Mixed capital company with private management & 1 & 1 & 2 \\
Mixed capital company with public management & 32 & 32 & 33 \\
\hline Grand Total & 217 & 422 & 1203 \\
\hline Source: SNIS. Developed by the authors & & &
\end{tabular}

\section{RESULTS ANALYSIS}

The information from SNIS dates back to 1995 and depends on the effort and willingness of municipalities and service providers to feed its database. As shown in Table 2, the number of municipalities records in 2000 corresponds to a fraction of $1 / 6$ of the 2010 quantitative, which shows the revolutionary construction of the database process.

Table 3 shows the income of service providers.

Table 3 - Operating Revenues from Providers in 2010, as to its Legal Nature

\begin{tabular}{|c|c|c|c|}
\hline Legal nature & $\begin{array}{l}\text { Total direct } \\
\text { operational } \\
\text { revenue } \\
\text { (R\$/year) }\end{array}$ & $\begin{array}{c}\mathrm{N}^{\mathbf{o}} \text { of } \\
\text { providers }\end{array}$ & $\begin{array}{l}\text { Average } \\
\text { operational } \\
\text { revenues } \\
(\mathrm{R} \$)\end{array}$ \\
\hline Direct public administration & 297.301 .844 & 700 & 425.325 \\
\hline Regional authority & 4.112 .486 .092 & 406 & 10.154 .287 \\
\hline Private company & 1.459 .212 .374 & 54 & 27.022 .451 \\
\hline Public company & 125.097 .727 & 5 & 25.019 .545 \\
\hline Social organization & 631.204 & 3 & 210.401 \\
\hline Mixed capital company with private management & 1.513 .584 .745 & 2 & 756.792 .373 \\
\hline Mixed capital company with public management & 23.414 .831 .787 & 33 & 709.540 .357 \\
\hline Grand Total & 30.923 .145 .773 & 1203 & 25.747 .832 \\
\hline
\end{tabular}

Source: SNIS. Developed by the authors

Providers may have local, micro-regional and regional coverage. Table 4 provides the profile of the providers on coverage and the percentage of direct operational revenues. In general, mixed capital companies have regional coverage. Other legal natures have eminently local character. 
Table 4 - Coverage of the Service Providers - 2010

\begin{tabular}{|c|c|c|c|c|c|c|}
\hline \multirow[t]{3}{*}{ Legal nature } & \multicolumn{6}{|c|}{ Coverage } \\
\hline & \multicolumn{2}{|c|}{ Local } & \multicolumn{2}{|c|}{ Micro-regional } & \multicolumn{2}{|c|}{ Regional } \\
\hline & $\begin{array}{c}\mathbf{N}^{\mathbf{o}} \text { of } \\
\text { providers }\end{array}$ & $\begin{array}{c}\% \text { of } \\
\text { Revenues }\end{array}$ & $\begin{array}{c}\mathbf{N}^{\mathbf{o}} \text { of } \\
\text { providers }\end{array}$ & $\begin{array}{c}\% \text { of } \\
\text { Revenues }\end{array}$ & $\begin{array}{c}\mathbf{N}^{\mathbf{o}} \text { of } \\
\text { providers }\end{array}$ & $\begin{array}{c}\% \text { of } \\
\text { Revenues }\end{array}$ \\
\hline Direct public administration & 700 & $100,0 \%$ & & & & \\
\hline Regional authority & 402 & $99,4 \%$ & 3 & $0,5 \%$ & 1 & $0,1 \%$ \\
\hline Private company & 50 & $79,4 \%$ & 3 & $8,9 \%$ & 1 & $11,8 \%$ \\
\hline Public company & 4 & $95,6 \%$ & & & 1 & $4,4 \%$ \\
\hline Social organization & 3 & $100,0 \%$ & & & & \\
\hline Mixed capital private management & 1 & $0,2 \%$ & & & 1 & $99,8 \%$ \\
\hline Mixed capital public management & 10 & $4,1 \%$ & & & 23 & $95,9 \%$ \\
\hline Grand Total & 1170 & $21,4 \%$ & 6 & $0,5 \%$ & 27 & $78,1 \%$ \\
\hline
\end{tabular}

Source: SNIS. Developed by the authors

\subsection{ANALYSIS OF THE PERFORMANCE OF WATER SUPPLY AND SANITATION SERVICE PROVIDERS}

Initially we will address the number one research question, consisting of a direct comparison between the contents of the SNIS, which reflect the performance of service providers from optics an economic, financial, administrative and operational viewpoint. For comparative purposes between the average rates, we shall only use information from 2010 . Table 5 shows which indexes were used, and for what purpose.

Table 5 - Indexes Used and the Purpose of Analysis

\begin{tabular}{|c|c|}
\hline Index & Purpose for its use \\
\hline IN004 - Average tariff practiced & $\begin{array}{l}\text { Verify whether the concession of services to } \\
\text { private companies result in higher charges. }\end{array}$ \\
\hline IN012 - Financial performance index & \multirow{6}{*}{$\begin{array}{l}\text { Verify if private companies have better } \\
\text { management skills than public entities under the } \\
\text { administrative and financial perspective. }\end{array}$} \\
\hline IN019 - Index productivity: Total active savings with staff & \\
\hline IN029 - Revenue evasion index & \\
\hline IN050 - Gross index of linear losses & \\
\hline IN054 - Revenue days committed to accounts receivable & \\
\hline IN102 - Total staff productivity index & \\
\hline IN064 - Operational margin with depreciation & \multirow{2}{*}{$\begin{array}{l}\text { Verify if the private company is able to achieve } \\
\text { superior returns to that of public entities. }\end{array}$} \\
\hline IN066 - Return on equity & \\
\hline IN015 - Sewage collection index & \multirow{5}{*}{$\begin{array}{l}\text { Verify that the service provided by private } \\
\text { companies is higher than that offered by public } \\
\text { entities. }\end{array}$} \\
\hline IN016 - Sewage treatment Index & \\
\hline IN046 - Treated sewage index referring to the water consumed & \\
\hline IN055 - Total water service index & \\
\hline IN057 - Water fluoridation index & \\
\hline
\end{tabular}

Table 6 presents the descriptive statistics of the listed indexes, as wel as KolmogorovSmirnov's test, which rejected normality for all variables. Thus, the significance of differences between means may not be based on ANOVA but in the Kruskal Wallis test. 
Table 6 - Descriptive Statistics and Normality Test of the Indexes Used

\begin{tabular}{|c|c|c|c|c|c|c|c|c|}
\hline \multirow[t]{2}{*}{ Index } & \multirow[t]{2}{*}{$\mathrm{N}^{\circ}$ Obs. } & \multicolumn{2}{|c|}{ Normal parameters } & \multicolumn{3}{|c|}{ Extreme differences } & \multirow{2}{*}{$\begin{array}{c}\text { Kolmogoro } \\
\text { v-Smirnov } \\
\text { Z }\end{array}$} & \multirow{2}{*}{$\begin{array}{c}\text { Sig. (2 } \\
\text { tails) }\end{array}$} \\
\hline & & Mean & $\begin{array}{l}\text { Standard } \\
\text { Deviation }\end{array}$ & $\begin{array}{c}\text { Absolu } \\
\text { te }\end{array}$ & Positive & Negative & & \\
\hline IN004 & 862 & 1,159 & 0,822 & 0,079 & 0,077 & $-0,079$ & 2,330 & 0,000 \\
\hline IN012 & 1196 & 84,158 & 61,172 & 0,100 & 0,100 & $-0,084$ & 3,470 & 0,000 \\
\hline IN019 & 1114 & 343,090 & 443,287 & 0,242 & 0,242 & $-0,233$ & 8,067 & 0,000 \\
\hline IN029 & 977 & 3,753 & 19,410 & 0,287 & 0,287 & $-0,260$ & 8,984 & 0,000 \\
\hline IN050 & 978 & 19,701 & 26,949 & 0,232 & 0,146 & $-0,232$ & 7,267 & 0,000 \\
\hline IN054 & 784 & 100,449 & 177,828 & 0,286 & 0,219 & $-0,286$ & 8,010 & 0,000 \\
\hline IN102 & 1160 & 328,079 & 438,814 & 0,243 & 0,243 & $-0,237$ & 8,282 & 0,000 \\
\hline IN064 & 89 & 18,700 & 33,192 & 0,154 & 0,154 & $-0,120$ & 1,453 & 0,029 \\
\hline IN066 & 86 & 12,643 & 256,950 & 0,324 & 0,286 & $-0,324$ & 3,002 & 0,000 \\
\hline IN015 & 525 & 66,890 & 28,774 & 0,223 & 0,091 & $-0,223$ & 5,119 & 0,000 \\
\hline IN016 & 611 & 51,226 & 46,372 & 0,249 & 0,232 & $-0,249$ & 6,154 & 0,000 \\
\hline IN046 & 524 & 32,999 & 35,725 & 0,193 & 0,193 & $-0,178$ & 4,408 & 0,000 \\
\hline IN055 & 985 & 79,305 & 20,512 & 0,156 & 0,156 & $-0,126$ & 4,912 & 0,000 \\
\hline IN057 & 836 & 59,168 & 46,043 & 0,264 & 0,248 & $-0,264$ & 7,621 & 0,000 \\
\hline
\end{tabular}

Table 7 presents the average scores obtained in accordance with the legal nature of the service providers, Kruskal Wallis test and the classification of private companies in relation to the analyzed content.

Table 7 - Average Indexes Observed - 2010

\begin{tabular}{|c|c|c|c|c|c|c|c|c|c|c|c|}
\hline \multirow[t]{3}{*}{ Index } & \multicolumn{7}{|c|}{ Legal nature } & \multirow[t]{3}{*}{ Sig. } & \multirow{3}{*}{$\begin{array}{l}\mathrm{H} 0 \\
(* 1)\end{array}$} & \multirow{2}{*}{\multicolumn{2}{|c|}{$\begin{array}{c}\text { Classification of private } \\
\text { companies }\end{array}$}} \\
\hline & \multirow{2}{*}{$\begin{array}{c}\text { Direct } \\
\text { Public } \\
\text { Adm. }\end{array}$} & \multirow{2}{*}{$\begin{array}{l}\text { Regional } \\
\text { authority }\end{array}$} & \multirow{2}{*}{$\begin{array}{l}\text { Private } \\
\text { company }\end{array}$} & \multirow{2}{*}{$\begin{array}{l}\text { Public } \\
\text { company }\end{array}$} & \multirow{2}{*}{$\begin{array}{c}\text { Social } \\
\text { organi- } \\
\text { zation }\end{array}$} & \multicolumn{2}{|c|}{ Mixed capital } & & & & \\
\hline & & & & & & $\begin{array}{l}\text { Private } \\
\text { Adm. }\end{array}$ & $\begin{array}{l}\text { Public } \\
\text { Adm. }\end{array}$ & & & General & $\begin{array}{c}\text { Relevant } \\
(* 2)\end{array}$ \\
\hline $\mathrm{N}^{\circ}$ obs. & 700 & 406 & 54 & 5 & 3 & 2 & 33 & - & - & - & - \\
\hline IN004 & 0,84 & 1,26 & 1,89 & 1,34 & 2,11 & 5,43 & 2,21 & 0,000 & Reject & $4^{\mathrm{a}}$ & $3^{\mathrm{a}}$ \\
\hline IN012 & 61,45 & 114,58 & 130,80 & 146,13 & 167,82 & 112,71 & 93,38 & 0,000 & Reject & $3^{\mathrm{a}}$ & $1^{\mathrm{a}}$ \\
\hline IN019 & 411,28 & 241,31 & 303,07 & 286,51 & 126,29 & 280,02 & 342,68 & 0,000 & Reject & $3^{\mathrm{a}}$ & $3^{\mathrm{a}}$ \\
\hline IN029 & 6,03 & 0,06 & 7,77 & 14,56 & 0,00 & $-0,13$ & 8,42 & 0,000 & Reject & $5^{\mathrm{a}}$ & $3^{\mathrm{a}}$ \\
\hline IN050 & 13,92 & 25,42 & 16,58 & 13,18 & 2,66 & 17,14 & 41,22 & 0,000 & Reject & $4^{\mathrm{a}}$ & $2^{a}$ \\
\hline IN054 & 100,55 & 100,63 & 71,23 & 88,00 & 2,00 & 50,00 & 155,34 & 0,000 & Reject & $3^{\mathrm{a}}$ & $1^{\mathrm{a}}$ \\
\hline IN102 & 402,41 & 222,49 & 257,10 & 246,77 & 125,12 & 225,77 & 267,57 & 0,000 & Reject & $3^{\mathrm{a}}$ & $3^{\mathrm{a}}$ \\
\hline IN064 & & & 32,65 & $-17,32$ & 0,00 & $-21,65$ & 3,85 & 0,001 & Reject & $1^{\mathrm{a}}$ & $1^{\mathrm{a}}$ \\
\hline IN066 & & & 14,93 & 25,34 & $-111,11$ & 57,64 & 9,07 & 0,322 & Accept & - & - \\
\hline IN015 & 69,70 & 67,51 & 70,05 & 54,37 & & 61,09 & 41,79 & 0,000 & Reject & $1^{\mathrm{a}}$ & $1^{\mathrm{a}}$ \\
\hline IN016 & 42,94 & 55,14 & 80,23 & 51,27 & & 99,24 & 68,60 & 0,000 & Reject & $2^{a}$ & $1^{\mathrm{a}}$ \\
\hline IN046 & 32,83 & 31,60 & 55,28 & 20,96 & & 60,62 & 25,59 & 0,006 & Reject & $2^{\mathrm{a}}$ & $1^{\mathrm{a}}$ \\
\hline IN055 & 76,71 & 82,86 & 79,18 & 81,92 & 57,90 & 45,77 & 77,42 & 0,032 & Reject & $3^{\mathrm{a}}$ & $2^{\mathrm{a}}$ \\
\hline IN057 & 45,29 & 73,34 & 62,76 & 62,58 & 43,25 & 94,00 & 57,04 & 0,000 & Reject & $3^{\mathrm{a}}$ & $2^{a}$ \\
\hline
\end{tabular}

Notes:

a) IN004, IN029, IN050 and IN054 have an inverse classification, that is, the lowest index is more desirable.

b) $(* 1) \mathrm{H} 0$ represents the hypothesis of which the observations are statistically equal.

c) (*2) Excludes public companies, social organizations and mixed capital companies with private administration, due to the irrelevance of the number of providers classified as such.

Source: SNIS. Developed by the authors

By using as a reference, the classification where the least significant legal natures were excluded, we verified that private providers are located in the first or second position in 9 out of 14 possible situations, which demonstrates its differentiated performance in the evaluated aspects. Private providers have better financial performance, are more efficient in charging, have greater operational margin; at the same time, the concessions which they manage provide more comprehensive services in terms of sewage collection and treatment and are the 
second regarding the supply and treatment of water. On the other hand they assume the third place in terms of tariffs practiced. Curiously, they assume only the third place in personnel productivity indexes, whether we are referring to productivity based on the number of active savings (IN019) based on the number of water and sewage connections (IN102).

\subsection{WILLINGNESS TO INVEST}

One of the reasons to concede services to the private sector resides in the willingness to make new investments, in view of its ability to raise funds. Thus, one aspect to be investigated is: "Does the private partner, in fact, invest more?".

Table 8 presents information available on investments made in the last five years of the past decade (including from 2006 to 2010) distinguishing on the source of funds (service provider, municipality or state government). Note that when the service provider is a private company, the invested public resources are virtually non-existent.

Table 8 - Investments Made in Water Supply in Sanitation - 2006 to 2010

\begin{tabular}{|c|c|c|c|c|c|c|c|}
\hline \multirow[t]{2}{*}{ Legal nature } & \multicolumn{2}{|c|}{$\begin{array}{c}\text { Made by the } \\
\text { service provider }\end{array}$} & \multicolumn{2}{|c|}{$\begin{array}{c}\text { Made by } \\
\text { municipalities }\end{array}$} & \multicolumn{2}{|c|}{$\begin{array}{l}\text { Made by the } \\
\text { State }\end{array}$} & \multirow[t]{2}{*}{$\begin{array}{c}\text { Total } \\
\text { investment }\end{array}$} \\
\hline & $\mathbf{R} \$$ & $\%$ & $\mathbf{R} \$$ & $\%$ & $\mathbf{R} \$$ & $\%$ & \\
\hline Direct public administration & 381.889 & 94,8 & 0 & 0,0 & 21.125 & 5,2 & 403.014 \\
\hline Regional authority & 3.844 .585 & 93,8 & 196.854 & 4,8 & 59.198 & 1,4 & 4.100 .637 \\
\hline Private company & 1.416 .996 & 99,4 & 8.862 & 0,6 & 0 & 0,0 & 1.425 .858 \\
\hline Public company & 134.423 & 100,0 & 0 & 0,0 & 0 & 0,0 & 134.423 \\
\hline Social organization & 47.192 & 100,0 & 0 & 0,0 & 0 & 0,0 & 47.192 \\
\hline Mixed capital private management & 1.920 .931 & 100,0 & 0 & 0,0 & 0 & 0,0 & 1.920 .931 \\
\hline Mixed capital public management & $\begin{array}{r}22.137 .94 \\
5\end{array}$ & 96,0 & 30.853 & 0,1 & 895.425 & 3,9 & 23.064 .224 \\
\hline Grand Total & $\begin{array}{r}29.883 .96 \\
2\end{array}$ & 96,1 & 236.570 & 0,8 & 975.748 & 3,1 & 31.096 .280 \\
\hline
\end{tabular}

Source: SNIS. Developed by the authors

In terms of the amount invested, mixed capital companies are the ones who invest the most. These companies have large dimensions, with average operating revenues of $\mathrm{R} \$ 700$ million (Table 3), and manage basic sanitation in the big cities. This comparison should be put into perspective on the municipality's population. Table 9 makes this adjustment, with the per capita investment made by the service provider. By this criterion private companies rank the second place among those who invest the most, second only to mixed capital companies with private management. 
Table 9 - Average Investment per Capita Made by the Service Provider

\begin{tabular}{|c|c|c|c|c|c|c|}
\hline \multirow[t]{2}{*}{ Legal nature } & \multicolumn{6}{|c|}{ Reference year } \\
\hline & 2006 & 2007 & 2008 & 2009 & 2010 & $\begin{array}{r}\text { General } \\
\text { Mean }\end{array}$ \\
\hline Direct public administration & 19,08 & 20,63 & 22,40 & 22,97 & 23,46 & 22,24 \\
\hline Regional authority & 11,00 & 19,11 & 18,77 & 17,16 & 18,86 & 17,10 \\
\hline Private company & 50,85 & 29,60 & 27,36 & 24,04 & 30,87 & 32,22 \\
\hline Public company & 24,38 & 20,07 & 6,31 & 9,81 & 41,99 & 20,80 \\
\hline Social organization & - & - & 1,77 & 10,67 & 2,69 & 6,45 \\
\hline Mixed capital private management & 55,01 & 37,28 & 32,98 & 31,50 & 41,06 & 39,57 \\
\hline Mixed capital public management & 19,12 & 16,94 & 27,40 & 33,61 & 36,72 & 26,70 \\
\hline Grand Total & 16,94 & 20,22 & 20,88 & 20,64 & 22,47 & 20,50 \\
\hline
\end{tabular}

a) We consider only those situations where the investment made in the year differed from zero

b) Kolmogorov-Smirnov's test presented Z $=22.67$, or $\mathrm{Sig}=0.00$; therefore, it must reject normality.

c) Kruskal Wallis test the variable average investment per capita, grouped by the variable legal nature of the provider rejects the hypothesis that the populations are equal, with significance at 0.0001 .

Source: SNIS. Developed by the authors.

Of the above, we can claim that private companies invest more, per inhabitant, than all other legal natures, except for mixed capital companies with private management.

\subsection{SERVICE UNIVERSALIZATION}

In the spirit of Law 11.445 / 2007 to ensure the population access to the services of sanitation, it is justified to assess whether private service providers have shown higher performance in relation to public providers in achieving this goal.

The analysis of the access to services of water supply and sewage collection considered 3 indexes, namely:

- IN015 - Sewage collection index

- IN046 - Treated sewage index referring to the water consumed

- IN055 - Total water service index

Table 10 presents the means of the presented indexes. The water coverage index stood at around $83 \%$ in 2005, which means there is little room for growth in access to these services. The index for sewage collection indicates values close to $60 \%$ in 2005 , which is a long way to the achievement of universal service. With regard to the sewage treatment deficiency is even greater, where the corresponding index reaches $23 \%$ on average of the municipalities. 
Table 10 - Service Index, by Legal Nature of the Provider

\begin{tabular}{|c|c|c|c|c|c|c|}
\hline \multirow[t]{2}{*}{ Legal nature } & \multicolumn{2}{|c|}{ IN015 } & \multicolumn{2}{|c|}{ IN046 } & \multicolumn{2}{|c|}{ IN055 } \\
\hline & 2005 & 2010 & 2005 & 2010 & 2005 & 2010 \\
\hline Direct public administration & 55,91 & 69,70 & 18,77 & 32,83 & 81,76 & 76,71 \\
\hline Regional authority & 65,79 & 67,51 & 24,24 & 31,60 & 84,07 & 82,86 \\
\hline Private company & 55,01 & 70,05 & 21,61 & 55,28 & 83,50 & 79,18 \\
\hline Public company & 81,08 & 54,37 & 25,73 & 20,96 & 93,02 & 81,92 \\
\hline Social organization & 50,62 & 61,09 & 47,71 & 60,62 & 85,84 & 87,92 \\
\hline $\begin{array}{l}\text { Mixed capital private management } \\
\text { Mixed capital public management }\end{array}$ & 39,40 & 41,79 & 24,37 & 25,59 & 78,63 & $\begin{array}{l}77,42 \\
57,90\end{array}$ \\
\hline General Mean & 60,29 & 66,89 & 23,30 & 33,00 & 83,17 & 79,30 \\
\hline
\end{tabular}

Source: SNIS. Developed by the authors.

Growth in access to services will be measured by comparing the 2005 figures with those measured for 2010. Thus, three variables were created:

$-\Delta_{\mathrm{IN} 015}:$ difference of the index of sewage collection between 2005 and 2010;

$-\Delta_{\text {IN046: }}$ difference of the index of sewage treatment referring to the water consumed between 2005 and 2010;

$-\Delta_{\mathrm{IN} 055}$, difference of the index of the total water service between 2005 and 2010.

Results are presented in Table 11.

Table 11 - Average evolution in access to services, by legal nature of the provider

\begin{tabular}{l|c|c|c}
\hline Legal nature & $\Delta_{\text {IN015 }}$ & $\Delta_{\text {IN046 }}$ & $\begin{array}{c}\Delta_{\text {IN055 }} \\
\text { Water service }\end{array}$ \\
\hline Direct public administration & Sewage collection & Sewage treatment & $-3,58$ \\
\hline Regional authority & 3,10 & 5,75 & $-0,90$ \\
\hline Private company & 2,19 & 9,13 & $-0,73$ \\
\hline Public company & 26,28 & 39,36 & $-3,12$ \\
\hline Social organization & $-4,89$ & 10,60 & 2,08 \\
\hline Mixed capital private management & 10,47 & 12,91 & $-2,76$ \\
\hline Notes: & $-2,01$ & $-0,53$ &
\end{tabular}

a) By neglecting the records in which the change in nature of the provider occurred, or in which the indexes IN015 IN046 and IN055 did not present valid numbers in 2005 and 2010.

b) Kolmogorov-Smirnov's test presented significances at $0.003,0.000$ and 0.009 for the variables $\Delta_{\mathrm{IN} 015}, \quad \Delta_{\mathrm{IN} 046}$ and $\Delta_{\mathrm{IN} 055}$, respectively. Therefore, in all cases we must reject normality.

c) Kruskal Wallis' test for the variables $\Delta_{\mathrm{IN} 015}$ and $\Delta_{\mathrm{IN} 046}$, grouped by the legal nature of the provider, we reject the hypothesis that the means are equal, with significances at 0.013 and 0.000 , respectively. The same test supports the hypothesis that equality of the means for the variable $\Delta_{\mathrm{IN} 055}$ with significance of 0.634 .

Source: SNIS. Developed by the authors.

With regards to water supply, there is no significance for the difference between the growth of the indexes of the different types of providers, which is justified by the occurring high level of service in 2005. However, private service providers have provided the largest 
growth for the indexes related to the collection and treatment of sewage. It is evident, therefore, that public officials should consider the possibility of delegating to the private partner the provision of collection and treatment of sewage services, in order to achieve the goal of universalization of services that the Law 11.445/2007 deals with.

\subsection{THE ABILITY TO COMMUNICATE PRODUCTIVITY GAINS}

The bidding for hiring a private agent aimed at the provision of public services is a competitive process, causing this agent to reduce their prices until the desired returns limit and pushing them to the constant pursuit of productivity and cost reduction. Public administration has no such motivation, for it prioritizes the bureaucracy, hierarchy and the administrative processes. It is expected that the tariffs practiced by private providers are more correlated to the cost structure than those practiced by public providers.

Productivity gains from concessions open the possibility of reducing public tariffs. Based on this, some regulatory agencies, among which ARSESP (Regulatory Agency for Sanitation and Energy of the State of São Paulo State) (2013), have adopted in the contracts a productivity factor, also called Factor $\mathrm{X}$, whose objective is to share these gains with the population served; thus, this factor is a reducer of the tariff practiced.

If the relationship between tariffs in a given index of productivity is inelastic, the possibility of transferring the benefits to the users of the services is limited and there would be other explanations for the level of tariffs practiced. Take for example, the situation in which the water supply and sanitation services are fulfilled by the direct public administration and that part of the collection with the services is used to fund other public expenditures; thus, other factors that explain the practiced tariff level other than the costs incurred by the water supply and sanitation service.

It should be noted that some rates are directly proportional to the tariff, as those indexes of expenses and losses. In this category are the indexes IN003, IN008, IN026, IN027, IN029 and IN060. Other indexes are inversely proportional to the tariff though, as the productivity and scale indexes. The indexes IN017, IN019, IN048 and IN102 fall into this category. The following tables bring these indexes.

Static panels were processed with fixed and random effect. Table 12 presents the Hausman's test, which indicated the model with fixed effects as the most suitable. 
Table 12 - Hausman's Test

\begin{tabular}{c|l|cc}
\hline $\begin{array}{c}\text { Regr } \\
. N^{\mathbf{0}}\end{array}$ & \multicolumn{1}{c}{ Independent variable studied (Vartest) } & $\chi^{2}$ & Prob> $\chi^{2}$ \\
\hline \multicolumn{4}{c}{ Indexes directly proportional to the tariffs } \\
\hline 1 & IN003 - Total expenditure on services per $\mathrm{m}^{3}$ billed & 40,76 & 0,0000 \\
\hline 2 & IN008 - Average annual expenditure per employee & 25,12 & 0,0000 \\
\hline 3 & IN026 - Operational expenditure per m $^{3}$ billed & 48,99 & 0,0000 \\
\hline 4 & IN027 - Operational expenditure per savings & 38,93 & 0,0000 \\
\hline 5 & IN029 - Revenue evasion index & 13,83 & 0,0167 \\
\hline 6 & IN060 - Expenditure index for electricity consumption (water + sewage) & 17,44 & 0,0037 \\
\hline & Indexes inversely proportional to the tariffs & 21,04 & 0,0008 \\
\hline 7 & IN017 - Water consumption billed by savings & 63,80 & 0,0000 \\
\hline 8 & IN019 - Productivity index: active savings per person total (equiv.) & 0,0000 \\
\hline 9 & IN048 - Produc. index: own employees per 1.000 connections (water + sewage) & 89,51 & 0,0000 \\
\hline 10 & IN102 - Total personal productivity index (equivalent) & 40,84 & 0
\end{tabular}

Source: Developed by the authors.

Table 13 presents the coefficients of the static panel with fixed effects among the productivity or expenses indexes (explanatory variables), by the practiced water and sewage tariffs (IN004), the dependent variable. The dummy $\mathrm{D}_{2}$ was introduced, representative of the direct public administration, regional authorities and public companies; and dummy $\mathrm{D}_{3}$, relative to the companies with mixed capital with public and private management. As the table's objective is to verify the correlation between a given index of productivity and the value of the tariff, the information of interest in these regressions are the coefficients of the interaction variables $\beta_{2}$ and $\beta_{3}$, and not the constants $\alpha_{2}$ and $\alpha_{3}$.

Table 13 - Regression Coefficients Between the Productivity Indexes and the Practiced Tariff

\begin{tabular}{|c|c|c|c|c|c|c|c|c|}
\hline \multicolumn{9}{|c|}{ Dependent variable: Practiced tariff - IN004 } \\
\hline \multirow{2}{*}{$\begin{array}{l}\text { Reg. Vartest } \\
\text { No }^{\circ}\end{array}$} & \multicolumn{6}{|c|}{ Coefficient } & \multirow[t]{2}{*}{$\mathbf{R}^{2}$} & \multirow{2}{*}{ 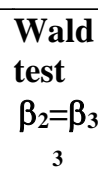 } \\
\hline & $\begin{array}{c}\text { Vartest } \\
\left(\beta_{1}\right)\end{array}$ & $\begin{array}{c}\mathbf{D}_{2} \times \\
\text { Vartest } \\
\left(\beta_{2}\right) \\
\end{array}$ & $\begin{array}{c}\mathbf{D}_{\mathbf{3}} \times \\
\text { Vartest } \\
\left(\boldsymbol{\beta}_{\mathbf{3}}\right) \\
\end{array}$ & $\begin{array}{c}\text { Const. } \\
\left(\alpha_{1}\right)\end{array}$ & $\begin{array}{c}\mathbf{D}_{2} \\
\left(\alpha_{2}\right)\end{array}$ & $\begin{array}{c}\mathbf{D}_{3} \\
\left(\alpha_{3}\right)\end{array}$ & & \\
\hline \multicolumn{9}{|c|}{ Indexes directly proportional to the tariffs } \\
\hline \multirow[t]{2}{*}{$\begin{array}{ll}1 & \text { IN003 }\end{array}$} & $0,9118 * * *$ & $-0,0085$ & $-0,1596 *$ & 0,1764 & $-0,0410$ & $-0,0502$ & \multirow[t]{2}{*}{$0,4930,000$} & \multirow[t]{2}{*}{0,004} \\
\hline & $(0,000)$ & $(0,917)$ & $(0,061)$ & $(0,224)$ & $(0,788)$ & $(0,790)$ & & \\
\hline \multirow[t]{2}{*}{$\begin{array}{ll}2 & \text { IN008 }\end{array}$} & $0,00006^{* * *}$ & $-0,00003 * * *$ & $-0,00003^{* * *}$ & $-0,1917$ & $0,6481 * * *$ & $0,6224 * *$ & \multirow[t]{2}{*}{$0,2190,000$} & \multirow[t]{2}{*}{0,166} \\
\hline & $(0,000)$ & $(0,000)$ & $(0,000)$ & $(0,343)$ & $(0,002)$ & $(0,015)$ & & \\
\hline \multirow[t]{2}{*}{$\begin{array}{ll}3 & \text { IN026 }\end{array}$} & $1,1457 * * *$ & $-0,2046 * *$ & $-0,2613 * *$ & 0,1213 & 0,0367 & 0,0275 & \multirow[t]{2}{*}{$0,4740,000$} & \multirow[t]{2}{*}{0,355} \\
\hline & $(0,000)$ & $(0,049)$ & $(0,018)$ & $(0,430)$ & $(0,820)$ & $(0,889)$ & & \\
\hline \multirow[t]{2}{*}{$4 \quad$ IN027 } & $0,0067 * * *$ & $-0,0020 * *$ & $-0,0022 * *$ & 0,0983 & 0,1765 & 0,0788 & \multirow[t]{2}{*}{$0,3000,000$} & \multirow[t]{2}{*}{0,669} \\
\hline & $(0,000)$ & $(0,018)$ & $(0,012)$ & $(0,652)$ & $(0,442)$ & $(0,776)$ & & \\
\hline \multirow[t]{2}{*}{ IN029 } & $-0,0142 * *$ & $0,0151 * *$ & 0,0117 & $1,7146 * * *$ & $-0,6886^{* * *}$ & $-0,6584 * *$ & \multirow[t]{2}{*}{$0,0440,060$} & \multirow[t]{2}{*}{0,486} \\
\hline & $(0,022)$ & $(0,017)$ & $(0,136)$ & $(0,000)$ & $(0,004)$ & $(0,037)$ & & \\
\hline \multirow[t]{2}{*}{$6 \quad$ IN060 } & 0,3333 & $-0,1551$ & $-0,0629$ & $1,1619 * * *$ & $-0,1030$ & $-0,1236$ & \multirow[t]{2}{*}{$0,0120,545$} & \multirow[t]{2}{*}{0,883} \\
\hline & $(0,585)$ & $(0,802)$ & $(0,942)$ & $(0,000)$ & $(0,749)$ & $(0,800)$ & & \\
\hline
\end{tabular}




\begin{tabular}{|c|c|c|c|c|c|c|c|}
\hline \multicolumn{8}{|c|}{ Indexes inversely proportional to the tariff } \\
\hline \multirow[t]{2}{*}{ IN017 } & $-0,1002 * * *$ & $0,0757 * * *$ & $-0,0109$ & $3,0878 * * *-1,6273 * * *$ & $-0,0240$ & \multirow{2}{*}{\multicolumn{2}{|c|}{$0,2110,000 \quad 0,000$}} \\
\hline & $(0,000)$ & $(0,008)$ & $(0,767)$ & $(0,002)$ & $(0,973)$ & & \\
\hline \multirow[t]{2}{*}{ IN019 } & $-0,0027 * *$ & $0,0030 * *$ & $0,0077 * * *$ & $2,2812 * * *-1,3462 * * *$ & $-2,5015 * * *$ & \multirow[t]{2}{*}{$0,031 \quad 0,000$} & \multirow[t]{2}{*}{0,000} \\
\hline & $(0,044)$ & $(0,030)$ & $(0,000)$ & $\begin{array}{l}2,2812 * * * \\
(0,000)\end{array}$ & $(0,000)$ & & \\
\hline \multirow[t]{2}{*}{ IN048 } & $-0,4506 * * *$ & $0,3956 * * *$ & 0,0888 & \multirow{2}{*}{\multicolumn{2}{|c|}{$\begin{array}{ccc}2,7084 * * * & -1,4775 * * * & -0,2167 \\
(0,000) & (0,003) & (0,723)\end{array}$}} & \multirow{2}{*}{\multicolumn{2}{|c|}{$0,001 \quad 0,000 \quad 0,000$}} \\
\hline & $(0,002)$ & $(0,008)$ & $(0,594)$ & & & & \\
\hline \multirow[t]{2}{*}{$10 \quad$ IN102 } & $-0,0017$ & 0,0014 & $0,0065^{* * *}$ & $1,9224 * * *-0,7963 *$ & \multirow{2}{*}{$\begin{array}{l}-1,7181^{* * *} \\
(0,006)\end{array}$} & \multirow[t]{2}{*}{$0,084 \quad 0,011$} & \multirow[t]{2}{*}{0,002} \\
\hline & $(0,233)$ & $(0,330)$ & $(0,003)$ & $(0,076)$ & & & \\
\hline
\end{tabular}

Notes: Significance Level: (***) 1\%, (**) 5\%, and (*) $10 \%$.

Source: Developed by the authors.

Based on the results from Table 13 we can establish a classification whose rationale is presented in the following examples:

Regression 4: IN0026 refers to operational expenditure and it should be directly proportional to the tariff charged (the greater the expenditure, the greater the tariff to be practiced). The coefficients $\beta_{1}, \beta_{2}$ and $\beta_{3}$ are significant, and their values are equal to 1.1457 , 0.2046 and -0.2613 , respectively. We conclude that $\beta_{1}$ is greater than $\beta_{1}+\beta_{2}$, and that $\beta_{1}$ is greater than $\beta_{1}+\beta_{3}$. Statistically, $\beta_{2}$ and $\beta_{3}$ are equal, for Wald's test result was 0.3552 for equality between them. We conclude that the private sector has better conditions to reduce tariffs when operational costs are reduced; the public sector though is tied with companies of mixed capital.

Regression 9: IN004, tariff is inversely proportional to IN017, one of the indexes related to productivity or scale (the greater productivity enables the reduction of tariff). The lower the declivity is the greater the possibility to transfer part of this productivity to the user of the service. By construction, $\beta_{1}$ reflects the declivity of the private sector and the declivity of the other sectors should be added to this. In Table 13 we read that $\beta_{1}=-0.1002$ and $\beta_{2}=0.0757$, both with significance, and $\beta_{3}$ is not significant. Thus, the declivity of the public sector amounts to $\beta_{1}+\beta_{2}=-0.0245$, a figure higher than the declivity -0.1002 of the private sector. As $\beta_{3}$ is statistically equal to zero, $\beta_{1}+\beta_{3}$ is statistically equal to $\beta_{1}$ and it is assumed that the declivity of companies is equal to the private sector. Needless to say, that the Wald's test rejects the equality of $\beta_{2}$ and $\beta_{3}$. Thus, we can conclude that, by classifying the sectors according to their ability to transfer greater reduction to the tariff in the hypothesis of economy of scales that index IN017 represents, so we have: first, in a tie comes the private sector and companies of mixed capital; and last comes the public sector. 
For the other regressions the procedure follows the same reasoning. Table 14 shows the classification obtained by the private sector, the public sector and mixed capital companies, regarding the declivity obtained in the regressions between price and productivity.

Table 14 - Classification of the Providers, Regarding the Relationship Between Productivity and Tariff

\begin{tabular}{|c|c|c|c|c|}
\hline Regr. & Var & \multicolumn{3}{|c|}{ Classification } \\
\hline $\mathrm{N}^{\mathrm{o}}$ & & $\begin{array}{l}\text { Private } \\
\text { Sector }\end{array}$ & $\begin{array}{l}\text { Public } \\
\text { Sector }\end{array}$ & $\begin{array}{l}\text { Mixed } \\
\text { Capital }\end{array}$ \\
\hline \multicolumn{5}{|c|}{ Indexes directly proportional to the tariff } \\
\hline 1 & IN003 & 1 & 2 & 3 \\
\hline 2 & IN008 & 1 & 2 & 2 \\
\hline 3 & IN026 & 1 & 2 & 2 \\
\hline 4 & IN027 & 1 & 2 & 2 \\
\hline 5 & IN029 & \multicolumn{3}{|c|}{ Inconclusive. Prob F > 0,05. } \\
\hline 6 & IN060 & \multicolumn{3}{|c|}{ Inconclusive. Prob $\mathrm{F}>>0,05$. } \\
\hline \multicolumn{5}{|c|}{ Indexes Inversely proportional to the tariff } \\
\hline 7 & IN017 & 1 & 3 & 1 \\
\hline 8 & IN019 & 1 & 2 & 3 \\
\hline 9 & IN048 & 1 & 3 & 1 \\
\hline 10 & IN102 & 1 & 1 & 3 \\
\hline
\end{tabular}

From the indexes related to expenses, and thus directly proportional to the tariff practiced, private companies presented higher declivity to those observed in the public sector and in companies of mixed capital for the indexes IN003, IN008, IN026 and IN027. For indexes IN029 (income evasion) and IN060 (electricity consumption) the numbers are inconclusive. Of the indexes related to productivity or scale and therefore, inversely proportional to the practiced tariff, private companies presented higher declivity in module for index IN019, and shared the first position with other sectors relative to indexes IN017, IN048, and IN102.

In sum, out of 10 indexes assessed, private companies presented a greater ability to communicate tariff reduction in eight situations, of which one ties with the public sector and two with mixed capital companies. The public sector presented better performance in one situation, in a tie with the private sector. Mixed capital companies perform better in two situations, both of them tied with other sectors. The indexes IN029 and IN060 present inconclusive results, since Prob. F $>0.05$. It can be said therefore that the tariffs of private service providers are more explained by costs or productivity level than the tariffs in the public sector or mixed capital companies.

The lower elasticity observed between tariff and public providers' productivity gains is in line with Da Motta and Moreira (2006), under which the income of the monopolist was not being shared with users for the calculation of the annual gains in productivity, since they do 
not explain the annual tariff variations. This decoupling process was more serious for regional operators as are mixed capital companies. It should be noted that at the time (1998-2002), the number of private providers was still incipient. In short, the conducted tests allow the following findings (Table 15):

\begin{tabular}{|c|l|l|}
\hline & Researched aspect & Findings \\
\hline 1 & $\begin{array}{l}\text { Operational, economic, financial, } \\
\text { administrative and tariff performance. }\end{array}$ & $\begin{array}{l}\text { Private companies occupied the first or second position 11 } \\
\text { times in 14 possible cases, when confronting directly the } \\
\text { selected indexes. }\end{array}$ \\
\hline 2 & Willingness to invest & $\begin{array}{l}\text { Private companies are the ones that invest the most except for } \\
\text { companies of mixed capital with private management. }\end{array}$ \\
\hline 3 & Service universalization & $\begin{array}{l}\text { Private companies have shown the greatest progress towards } \\
\text { achieving universal access to collection services and sewage } \\
\text { treatment, a particular aspect where Brazil has a greater } \\
\text { disability. }\end{array}$ \\
\hline 4 & $\begin{array}{l}\text { Ability to communicate productivity } \\
\text { gains regarding the practiced tariff }\end{array}$ & $\begin{array}{l}\text { The correlation between the public tariff and indexes denoting } \\
\text { productivity was the greatest for private companies, 8 out of } \\
\text { the 10 possible cases. In other words, the greater explanatory } \\
\text { power of the productivity factors on the tariff enables the } \\
\text { communication of productivity gains which favors service } \\
\text { users. }\end{array}$ \\
\hline
\end{tabular}

Table 15 - Findings

Source: Developed by the authors.

\section{CONCLUSIONS}

This study sought to comprehensively assess the performance of private companies in charge of providing water supply and sanitation services, compared to those managed by the public sector.

The evidence shows that private providers have a higher performance in several aspects; they are among the companies that invest the most, making them leaders in the quest for universalizing the service; they have, in fact, presented greater gains in the goal of universalizing the access to basic sanitation services; and apparently offer the opportunity to communicate further reductions to tariffs due to productivity gains, which favors finding the solution of Factor $\mathrm{X}$ in the concessions of water supply and sanitation.

The findings of this study can serve as a support and incentive for public officials to consider the private sector as an alternative to achieve the goal of Law 11.445/2007, which is to ensure the entire population access to basic sanitation services.

International assessments show no consistent results on the performance of companies in the sector and question social outcomes, as in many cases the private sector presents higher costs and tariffs than the public sector. Thus, competition should be encouraged and, in Brazil, incorporating productivity gain clauses in the concession contracts for basic sanitation, 
even for those struck for a longer time, can be an important measure to meet the principle of reasonable tariffs.

\section{REFERENCES}

ARSESP. Agência Reguladora de Saneamento e Energia do Estado de São Paulo. Nota Técnica Nº RTS 01/2013. Mar. 2013.

ASCHER, W.; KRUPP, C. (Org). Physical infrastructure development: balancing the growth, equity and environmental imperatives. Palgrave Macmillan, 2010.

BENNETT, A. Public enterprise reform and performance contracting. In: FARAZMAND, A. (Ed.). Privatization or public enterprise reform?: international case studies with implications for public management. Westport: Greenwood Press, 2001. p. 43-55.

BHATTACHARYYA, A. et al. Specification and estimation of the effect of ownership on the economic efficiency of the water utilities. Regional Science and Urban Economics, v. 25, n. 6, p. 759-784, 1995.

BORRAZ, F.; PAMPILLÓN, N. G.; OLARREAGA, M. Water nationalization and service quality. World Bank, 2013.

BRASIL. Lei no 11.445, de 05/01/2007. Diário Oficial [da] República Federativa do Brasil. Poder Executivo. Brasília, DF, 2007.

BROCKLEHURST, C.; JANSSENS, J. G. Innovative contracts, sound relationships: urban water sector reform in Senegal. World Bank, 2004.

DA MOTTA, R. S.; MOREIRA, A. Efficiency and regulation in the sanitation sector in Brazil. Utilities Policy, v. 14, n. 3, p. 185-195, 2006.

ESTACHE, A.; KOUASSI, E. Sector organization, governance, and the inefficiency of African water utilities. Governance, Regulation, and Finance Division, World Bank Institute, 2002.

EVANS, B. E.; BROCKLEHURST, C.; KARIUKI, M. New designs for water and sanitation transactions: making private sector participation work for the poor. Washington D.C: World Bank Water and Sanitation Program and PPIAF, 2004.

FERRO, G. et al. Efficiency in Brazil's water and sanitation sector and its relationship with regional provision, property and the independence of operators. Utilities Policy, v. 28, p. 42$51,2014$.

GARCÍA-SÁNCHEZ, I. M. Efficiency measurement in Spanish local government: the case of municipal water services. Review of Policy Research, v. 23, n. 2, p. 355-372, 2006.

GUASCH, J. L.; LAFFONT, J.; STRAUB, S. Renegotiation of concession contracts in Latin America: Evidence from the water and transport sectors. International Journal of Industrial Organization, v. 26, n. 2, p. 421-442, 2008. 
HAIR JUNIOR, J. F. et al. Análise multivariada de dados. 6. ed. Porto Alegre: Bookman, 2009.

HUTTON, G.; HALLER, L. Evaluation of the costs and benefits of water and sanitation improvements at the global level. Geneva: World Health Organization, 2004. Disponível em: <http://www.who.int/water_sanitation_health/wsh0404.pdf>. Acesso em: 01 dez. 2013.

IBGE. Instituto Brasileiro de Geografia e Estatística. Pesquisa nacional por amostras de domicilio: síntese dos indicadores 2012.

Pesquisa nacional de saneamento básico. 2008.

KESSIDES, I. N. Reforming infrastructure: privatization, regulation, and competition. Washington, DC: World Bank, 2004.

KIRKPATRICK, C.; PARKER, D.; ZHANG, Y. State versus private sector provision of water services in Africa: an empirical analysis. The World Bank Economic Review, v. 20, n. 1, p. 143-163, 2006.

LOCUSSOL, A. R.; FALL, M. Guiding principles for successful reforms of urban water supply and sanitation sectors. World Bank Group, 2009.

MELLO, L. R. Privatização e governança empresarial no Brasil. In: A privatização no Brasil: o caso dos serviços de utilidade pública. Rio de Janeiro: BNDES, Centro de Desenvolvimento da OCDE, 1999.

OLIVEIRA, G. et al. Parceria público-privada Alto Tietê: estudo de caso da primeira PPP da Sabesp. In: OLIVEIRA, G.; OLIVEIRA FILHO, L.C. (Org.). Parcerias público-privadas: experiências, desafios e propostas. Rio de Janeiro: LTC, 2013.

PINHEIRO, A. C. Momento de definição na infraestrutura brasileira. In: OLIVEIRA, G.; OLIVEIRA FILHO, L. C. (Org). Parcerias Público-Privadas: Experiências, Desafios e Propostas. Rio de Janeiro: LTC, 2013.

PNUD. Programa das Nações Unidas para o Desenvolvimento. Summary human development report 2006. Beyond scarcity: power, poverty and the global water crisis. New York: Palgrave Macmillan, 2006.

RENZETTI, S.; DUPONT, D. Ownership and performance of water utilities. Greener management international, v. 2003, n. 42, p. 9-19, 2003.

RUESTER, S.; ZSCHILLE, M. The impact of governance structure on firm performance: An application to the German water distribution sector. Utilities Policy, v. 18, n. 3, p. 154-162, 2010.

SAAL, D. S.; PARKER, D.; WEYMAN-JONES, T. Determining the contribution of technical change, efficiency change and scale change to productivity growth in the privatized English and Welsh water and sewerage industry: 1985-2000. Journal of Productivity Analysis, v. 28, n. 1-2, p. 127-139, 2007. 
SABBIONI, G. Efficiency in the Brazilian sanitation sector. Utilities Policy, v. 16, n. 1, p. 11-20, 2008.

SHINOHARA, D. Y.; SAVOIA, J. R. F. Parcerias público-privadas no Brasil. Barueri, SP: Manole, 2008.

SILVESTRE, H. C. Public-private partnership and corporate public sector organizations: alternative ways to increase social performance in the Portuguese water sector? Utilities Policy, v. 22, p. 41-49, 2012.

SNIS. Sistema Nacional de Informações sobre Saneamento. Séries históricas. Disponível em <http://www.snis.gov.br/>. Acesso em: 01 nov. 2013.

STOCK, J. H.; WATSON, M.W. Econometria. São Paulo: Pearson, 2004.

TUPPER, H. C.; RESENDE, M. Efficiency and regulatory issues in the Brazilian water and sewage sector: an empirical study. Utilities Policy, v. 12, n. 1, p. 29-40, 2004.

WALTER, M. et al. Quo vadis efficiency analysis of water distribution? A comparative literature review. Utilities Policy, v. 17, n. 3, p. 225-232, 2009.

WOOLDRIDGE, J. M. Introdução à econometria: uma abordagem moderna. São Paulo, Cengage Learning, 2012. 